instrumenta za oblikovanje globalnih diskurzov edukacijskih politik in kot baze dokazov za ustvarjanje politik $\mathrm{v}$ različnih nacionalnih kontekstih odvisna predvsem od tega, da dosežke primarno pripisujemo politikam." Pod krinko suhega in sterilnega pozitivizma je kompleksnost edukacije zreducirana predvsem na tehnični problem, ki išče odpravo svojih težav, objektivni pogoji, kot so razlike med spoli ali socialno-ekonomske neenakosti, pa so prepoznani zgolj kot zunanji dejavniki, ki jih lahko regulirajo taktično zastavljene politike. $S$ tem pa, kot opozarja W. Brown (2015), družbeni sistemi, med njimi tudi edukacija, postanejo v jedru depolitizirani, vprašanja družbenih razmerij moči so praktično prekrita in prikrita, prizadevanja za tovrstne premisleke o edukaciji pa diskreditirana kot premalo konstruktivna, zastarela ipd.

Zbrani prispevki neposredno obravnavajo specifične vidike privlačnosti raziskave PISA pri odločevalcih, brez pretenzije po ponujanju dokončnih odgovorov na to vprašanje. Obsežnejša analiza dominantne politične racionalnosti, ki sloni na zamiku $\mathrm{v}$ delovanju moči od vladanja $\mathrm{k}$ vladovanju (governance) in v jedru katere se nahaja ideja, ki jo je precej nedvoumno artikuliral tudi zgoraj omenjeni vodja strokovne skupine za pripravo bele knjige, ko je izjavil, da se je treba "razvijati, konstantno biti najboljši in tekmovati s svetom” (MMC, 22. januar 2020), pa je skozi nekatera besedila prisotna predvsem posredno in terja neko drugo delo, $\mathrm{z}$ drugačnim kategorialnim aparatom.

\title{
Literatura
}

Brown, W. (2015) Undoing the Demos. New York: ZONE BOOKS.

MMC. (22. januar 2020) Ministrstvo za šolstvo: Nova bela knjiga bo odziv na družbene spremembe. Spletna stran: https://www.rtvslo.si/slovenija/ ministrstvo-za-solstvo-nova-bela-knjiga-bo-odziv-na-druzbene-spremembe/512358 (pridobljeno I8. 7. 2020).

\section{Nika Šušteršič}

DOI: https://www.doi.org/10.32320/158I-6044.31(1-2)215-219

Orellana Garcia, Pelusa, Baldwin Lind, Paula (ur). Reading Achievement and Motivation in Boys and Girls - Field Studies and Methodological Approaches. Springer International Publishing, 2018.

Branje nam omogoča »stati na ramenih velikanov«, črpati znanje iz zgodovine človeštva in graditi na osnovah, ki so jih postavili tisti pred nami. Kot tako predstavlja četrto dimenzijo človeške evolucije in njegove 
pomembnosti ter pomena ne moremo dovolj poudariti, saj je predpogoj za uspeh posameznika in družbe kot celote. A če smo kot družba morda napredovali in osnovna pismenost prebivalstva ni več vprašljiva, je sedaj nastopil čas, da se posvetimo tudi kakovosti branja. Vsem, ki se ukvarjajo z izobraževanjem, je tako skupno vprašanje, kako sam proces opismenjevanja in razvoja kakovostnega branja zastaviti na strokovnih temeljih, ki bodo zagotavljali uspešno učenje, mišljenje in napredovanje vsakemu učencu v izobraževalnemu sistemu. Po prepričanju avtorjev v tej knjigi raziskovanje dejavnikov motivacije za branje lahko predstavlja tovrsten preboj v opismenjevanju prihodnjih generacij.

Knjiga predstavlja celovit pregled področja motivacije za branje in bralnih dosežkov, v njej pa so predstavljena tako teoretska izhodišča kot tudi konkretne raziskave in metaštudije. Na zanimiv način povezuje teoretične in praktične pristope $\mathrm{k}$ spodbujanju in preverjanju branja, poleg tega pa nam omogoči vpogled, koliko spremenljivosti v bralnih dosežkih lahko pojasnimo z dejavniki motivacije. Interdisciplinarno pokrije vsa temeljna področja, povezana $\mathrm{z}$ branjem in bralno motivacijo, in tako predstavlja dobro izhodišče za spoznavanje področja.

Najprej je predstavljen splošni pregled področja motivacije in prevladujočih teorij, pri čemer so izpostavljene glavne podobnosti in razlike med njimi. Knjiga teorije razdeli v tri priložnostne kategorije: teorije, ki vključujejo instinkte, potrebe in kot proces izpostavljajo ojačevanje vedenja; teorije, ki vključujejo prepričanja, vrednote in cilje, ter tretjo skupino, ki predstavlja nevroznanstvene in nevropsihološke poskuse razumevanja branja in bralne motivacije. S tovrstnim ozadjem je v nadaljevanju laže slediti dejavnikom, ki vplivajo na motivacijo za branje, saj se običajno teoretsko umestijo v eno od omenjenih skupin teorij.

V knjigi se različni avtorji spoprimejo z vprašanjem razlik med spoloma pri branju in motivaciji. Izpostavijo vpliv napačnih interpretacij in reprezentacij na motivacijo dečkov in deklic in iz zapisov v znanstveni literaturi izluščijo dva glavna miselna vzorca: tiste, ki trdijo, da so deklice v bralnem razumevanju boljše od fantov, in druge, ki trdijo, da razlik med spoloma ni. Z zgodovinskim pregledom raziskav in ugotovitev nakažejo, da do konca prve polovice dvajsetega stoletja raziskovalci ne odkrivajo nobenih razlik med spoloma. Temu sledi obdobje, ko se te razlike poudarja in celo razume kot naravno danost.

Ne glede na to, da razkorak med dečki in deklicami pri branju niha glede na specifično komponento branja, ki jo testiramo, pa usmerjanje pozornosti izključno na zaostajanje dečkov ali na drugi strani na visoke dosežke deklic spodbuja stališča, ki lahko vplivajo na navdušenje in vztrajnost učencev obeh spolov in s tem na njihovo motivacijo za branje. Dekleta 
imajo v večini raziskav $\mathrm{v}$ povprečju boljši dosežek pri branju, a tu ne gre za kako skrivnost; dekleta imajo namreč bolj pozitiven odnos do branja, preberejo več knjig, bolje berejo in imajo bolj razvito »bralno samopodobo « (ang. self-concept). Ko enkrat upoštevamo omenjene dejavnike, spol ne pojasnjuje več spremenljivosti v bralnih dosežkih.

Knjiga nas tudi uči, da pelje pot do višje motivacije fantov za branje preko spodbujanja branja vseh, tudi deklet. Npr. raziskovalci poročajo o večjem zadovoljstvu ob branju in višjih dosežkih tako fantov kot deklet na šolah, kjer je delež deklet večji. Do tega pride, ker imajo dekleta več socialnih stikov in v povprečju več prijateljev, v akademskem vrstniškem okolju $\mathrm{z}$ več dekleti pa je več podpore branju, ki je tudi bolj cenjeno.

Zelo zanimiv del knjige je posvečen okoljskim dejavnikom, ki vplivajo na motivacijo učencev za branje - družini s socialnimi, ekonomskimi in kulturnimi značilnostmi, vplivu sovrstnikov in vplivu države (družbe), v kateri živijo. Presenetljiva je npr. ugotovitev o razlikah v tem, kako fantje in dekleta izkoristijo socialno-ekonomski potencial svojega družinskega okolja. Po raziskavah sodeč fantje več pridobijo od izobraževalnih virov, ki so na voljo doma, dekleta pa bolje izkoristijo socialni kapital družine (npr. multikulturne stike družine z okoljem).

Knjiga poudarja pomen majhne razslojenosti v družbi oziroma vpliv neenakosti. Ne gre le za življenje pod pragom revščine in prikrajšanost za osnovne dobrine na eni strani in zelo visok SES na drugi strani, ampak za splošno dobrobit. Večja enakost namreč predstavlja tudi večjo enakost izobraževalnih virov. Ker z naraščanjem količine virov dosežki ne naraščajo linearno, ampak pride do zmanjševanja učinka (angl. diminishing return), je pomembno, da ima kar največji del populacije zagotovljen relativno pester osnovni nabor virov. To ima pozitiven učinek tudi zaradi posledičnih socialnih interakcij med učenci, saj se človek raje druži s sebi podobnimi, in če so si učenci z vidika družbene (ne)enakosti bolj podobni, potem se na ta način povečuje tudi socialna interakcija med njimi in vsi bolj napredujejo, povezanost dosežkov z značilnostmi družinskega okolja pa je nižja. Zanimivo je v državah $\mathrm{z}$ večjo izkazano družbeno enakostjo običajno razkorak v dosežkih v prid deklet večji, saj širok javni nabor izobraževalnih virov, ki je dostopen vsem, bolj koristi njim oziroma ga bolje izkoristijo.

Cilj šolanja mora biti motiviranje vseh učencev za branje. Ker gre za veščino, ki jo posameznik začne pridobivati že $\mathrm{v}$ otroštvu, je zelo pomembno usklajeno in tvorno sodelovanje staršev in šole. Pomembna je usklajenost, saj le v pozitivnem okolju spodbud in primerne zahtevnosti nastajajo izkušnje uspeha, ki ojačujejo zaznavo lastne uspešnosti pri branju in spodbujajo tako motivacijo kot druge značilnosti, ki vodijo učenca do uspešnega bralca. 
Starši z višjo izobrazbo bodo v povprečju bolje strukturirali otrokov čas, organizirali redne urice za branje, pohvalili in nagradili otroke za izkazan trud in jim pomagali ozavestiti posledice nezavzetosti. Na ta način bodo spodbujali zavzetost in motivacijo, vztrajnost in učne navade in posledično tudi višje dosežke pri usvajanju branja. Ker pa vsi učenci ne izhajajo iz enakega okolja, se mora šola truditi tovrstne pogoje nuditi kar največ otrokom in tako zagotavljati visoke dosežke za vse učence.

V sklepnem delu knjige so opisane posamezne konkretne raziskave na polju motivacije za branje. Prva raziskava npr. izpostavlja pomen motivacije za branje $\mathrm{v}$ vrtcu in prvih letih šolanja, še posebno za otroke, ki jim branje dela težave. Druga raziskava ima podobno raziskovalno vprašanje, a nekaj let starejše učence (3., 4. in 5. razred), in ugotavlja, kako iz leta v leto raste delež variance bralnega dosežka, ki ga pojasnjuje učenčeva zaznava lastne učinkovitosti branja (angl. self concept). Ostale raziskave predstavljajo podobne ugotovitve, a v različnih kontekstih (Finska, Tajvan) in pri različno starih učencih. Več raziskav osvetli tudi pomen različnih pristopov $\mathrm{k}$ poučevanju, ki spodbujajo bralno motivacijo, in pomen privlačnosti učnega gradiva za mlade bralce, specifično tudi za fante.

Knjiga je na eni strani zelo zanimiva za raziskovalce v polju branja, bralne motivacije in dejavnikov, ki vplivajo na branje (in bralno motivacijo), na drugi strani pa tudi za šolnike, starše in vse, ki se z branjem svojih otrok in učencev srečujejo neposredno v vsakodnevnih situacijah. Zelo konkretni in kakovostni opisi ugotovitev o značilnostih okolja, ki prispevajo k motivaciji za branje, ter raziskave o uspešnih pristopih poučevanja namreč nudijo veliko priložnosti za dobro razumevanje vplivov navedenih dejavnikov in omogočajo pripravo konkretnih aktivnosti, ki lahko motivacijo povečujejo. Z naborom tako teoretičnih kot empiričnih tem knjiga ustvari kritično maso, iz katere je laže izluščiti trenutno aktualna spoznanja o motivaciji za branje in jih umestiti v prakso. Učenci, pa naj gre za fante ali dekleta, se namreč učijo na različne načine in en sam pristop ne deluje za vse. S primerno diferenciacijo pa lahko napredujejo vsi.

\section{Gašper Cankar}

